RAGASSI, CF; CARVALHO, ADF; SILVA, GO; PEREIRA, GE; PEREIRA, AS. 2020. Performance of advanced potato genotypes in organic and conventional production systems. Horticultura Brasileira 38: 53-57. DOI - http://dx.doi.org/10.1590/S0102-053620200108

\title{
Performance of advanced potato genotypes in organic and conventional production systems
}

\author{
Carlos Francisco Ragassi 1무; Agnaldo DF de Carvalho ${ }^{1 \mathbb{D}}$; Giovani Olegário da Silva ${ }^{1 \mathbb{D}}$; Gabriel Emiliano \\ Pereira ${ }^{1,2} \mathbb{D}$; Arione da S Pereira ${ }^{3} \mathbb{D}$
}

'Embrapa Hortaliças, Brasília-DF, Brasil; carlos.ragassi@embrapa.br; agnaldo.carvalho@embrapa.br; giovani.olegario@embrapa.br; ${ }^{2}$ Faculdade de Agronomia e Medicina Veterinária, Universidade de Brasília (UnB), Brasília-DF, Brasil; gb.emiliano28@gmail.com; ${ }^{3}$ Embrapa Clima Temperado, Pelotas-RS, Brasil; arione.pereira@embrapa.br

\begin{abstract}
Potato is responsive to intensive agricultural input use; however, it can be produced in less intensive production systems (such as the organic system) by using appropriate production techniques and genotypes adapted to this system. This study aimed to evaluate the performance of advanced potato genotypes for tuber yield under conventional and organic production systems, in order to select potential genotypes to become new cultivars adapted to these systems. Fifteen advanced potato clones and two controls were evaluated under organic and conventional production systems, in 2016 and 2017, in Brasília-DF, Brazil. The experimental design was randomized blocks with three replicates and plots composed of two rows with 10 plants each, spaced $0.35 \mathrm{~m}$ between plants and $0.80 \mathrm{~m}$ between rows. Total (mass) and marketable (mass and number of tubers) productivities were evaluated. Variance analysis showed significant differences among genotypes for all traits. Despite the lower average tuber yield in the organic system, selecting genotypes with high potential productivity was possible in this system, such as F158-08-01 and F158-08-02, showing high marketable tuber yield, with values equivalent to the conventional system. Clones F102-08-04, F13-0907, F-18-09-03, F-183-08-01, F-21-09-07, F31-08-05, F63-10-07 and F97-07-03 also outperformed the control cultivars in organic system. For conventional system, F158-08-01, F158-08-02 and F183-08-01 were superior, and F18-09-03, F21-09-07, F63-10-07, F97-07-03, PCDINV10 and PCDSE090 showed performance similar or superior to the most productive control (cultivar Asterix). Genotypes F158-0801 and F158-08-02 were superior in both conventional and organic systems, with potential to become new cultivars recommended for both production systems.
\end{abstract}

Keywords: Solanum tuberosum, agronomic evaluation, production systems.

\section{RESUMO}

Desempenho de genótipos de batata em sistema orgânico e convencional de produção

Embora seja responsiva ao uso intensivo de insumos agrícolas, a batata pode ser produzida em sistemas de produção menos intensivos, como o sistema orgânico, por meio do uso de técnicas de produção adequadas e genótipos adaptados. Nesse contexto, objetivou-se avaliar o desempenho de clones avançados de batata para caracteres componentes do rendimento de tubérculos em sistemas orgânico e convencional de produção, para a definição dos clones com maior potencial para se tornarem novas cultivares, adaptadas a esses sistemas. Foram avaliados 15 clones avançados de batata e duas cultivares testemunhas em sistemas orgânico e convencional de cultivo, nos anos 2016 e 2017 em Brasília-DF. O delineamento experimental foi blocos ao acaso com três repetições e parcelas compostas por duas linhas com 10 plantas cada, espaçadas $0,35 \mathrm{~m}$ entre plantas e $0,80 \mathrm{~m}$ entre linhas. Foram avaliadas a produtividade total (massa) e comercial (massa e número de tubérculos). A análise de variância mostrou diferenças significativas entre os genótipos para todos os caracteres. Apesar do menor rendimento médio de tubérculos em sistema orgânico, foi possível selecionar clones com elevado potencial produtivo neste sistema, principalmente os clones F158-08-01 e F158-08-02, com elevado rendimento de tubérculos comerciais, equivalentes ao do sistema convencional. Além destes, os clones F102-08-04, F13-09-07, F-18-09-03, F-183-08-01, F-2109-07, F31-08-05, F63-10-07 e F97-07-03 também superaram as cultivares testemunhas no sistema orgânico. Para o sistema convencional, os clones F158-08-01, F158-08-02 e F183-08-01 foram superiores e os clones F18-09-03, F21-09-07, F63-10-07, F97-07-03, PCDINV10 e PCDSE090 apresentaram desempenho semelhante ou superior à testemunha mais produtiva (cultivar Asterix). Os clones F158-08-01 e F158-08-02, portanto, foram superiores em ambos os sistemas e possuem potencial para se tornarem novas cultivares com recomendação para esses dois sistemas de produção.

Palavras-chave: Solanum tuberosum, avaliação agronômica, sistemas de produção.

Received on March 8, 2019; accepted on January 7, 2020

$\mathrm{P}$ tato is the third most important human food source, being only surpassed by rice and wheat (FAOSTAT,
2015). Brazil produces about $3,854,054$ t of potato yearly, in an area of 125,548 hectares, with an average yield of 31.78 $\mathrm{t} \mathrm{ha}^{-1}$ (IBGE, 2019). The process of adoption of modern cultivation technique with investment in mechanization, 
irrigation, fertilization, quality of potato seeds and more effective control of pests and diseases results in the increasing productivity levels registered during the last decades. The productivity increase is possible because potato crop shows a very remarkable response to the crop management techniques, such as, the application of large quantities of fertilizers (Silva et al., 2018a), or an efficient chemical control of pests and diseases.

Potato crop can respond very well to improved management factors, it is also possible to grow potato in less intensive production systems, though, such as the organic cultivation. However, nutrients are less concentrated in an organic system when compared with a conventional production system, this latter one relying on high doses of chemical fertilizers applied to the planting line. Thus, cultivars which are more rustic and efficient in nutrient uptake, or which are more tolerant to diseases, are recommended for the organic system.

Potato productivity in organic system is generally lower than in conventional system. Nevertheless, the higher value paid for organic tubers, coupled with a milder requirement of the market for the good appearance and size of tubers, can maintain the profitability of the system. Besides, using appropriate management technique, such as, application of fertilizers and products which are allowed in organic system, provides a satisfactory productivity, and also an acceptable product quality (Nazareno, 2009).

The most used potato cultivars in Brazil are from Europe and they stand out for its good tuber appearance (fresh market) or suitability for processing, in the case of cultivars for industrial purposes. These cultivars were selected under weather and soil conditions, such as photoperiod, soil acidity, temperature and disease pressure highly contrastive to the conditions found in the potato cultivating areas in Brazil. These differences make European cultivars less adapted to cultivation in Brasil, requiring higher quantity of inputs in order to achieve higher productivity (Silva et al., 2014).
This study aimed to evaluate agronomic performance of advanced potato genotypes, using tuber yield in organic and conventional production systems for selecting those which show higher potential to become new cultivars adapted to both production systems.

\section{MATERIAL AND METHODS}

The experiments were installed in the experimental fields of Embrapa Hortaliças in Brasília-DF (15 55'44"S, $48^{\circ} 08^{\prime} 29^{\prime} \mathrm{W}, 999 \mathrm{~m}$ altitude and $15^{\circ} 56^{\prime} 30^{\prime \prime} \mathrm{S}, 48^{\circ} 08^{\prime} 22^{\prime \prime} \mathrm{W}, 999 \mathrm{~m}$ altitude), one experiment being carried out under conventional system and the other under organic system during the dry winter harvest (from May to September), 2016 and 2017. We evaluated advanced potato genotypes F-102-08-04, F-117-08-06, F-13-09-03, F-158-08-01, F-158-08-02, F-18-09-03, F-183-08-01, F-21-09-07, F-22-08-01, F-31-08-05, F-37-08-01, F-63-10-07, F-97-07-03, PCDINV10, PCDSE090 and control Agata (the most planted cultivar in Brazil for fresh market) and Asterix (the most planted in Brazil for industrial purposes). Cultivation periods (from planting to harvest) were from June 3, 2016 to October 7, 2016 and May 29, 2017 to October 2, 2017 for organic cultivation and from May 18, 2016 to September 15, 2016 and May 15, 2017 to September 14, 2017 for conventional cultivation. The difference between planting times and harvest considering conventional and organic systems (about 15 days) was due to operational need for scaling up the use of labor and machinery.

Plantings were carried out in the same areas, in each system, but in different plots in each year. Organic cultivation area is isolated from the conventional one, by trees and shrubs used as windbreaks. This area has been managed in the organic system for over 15 years. Before experiment installation, the area used in each year underwent fallow with spontaneous vegetation composed, predominantly, of grasses for, at least, 10 years.

The potato seed of the first cycle of experiments (2016) consisted of type II
(40 to $50 \mathrm{~mm}$ diameter) tubers harvested from a conventional production field planted with basic class tubers. The potato seeds were stored in a cold chamber at $4^{\circ} \mathrm{C}$ for 5 months before implanting the experiments. For 2017 cultivation, we used seed tubers of the same size class, obtained from the previous harvest in each system and stored in a cold chamber following harvest, at the same temperature, for 8 months.

Soil chemical characteristics at $0-20$ $\mathrm{cm}$ depth according to the analyses carried out in the first year of the experiment (implementation of the experiments) in organic system were: organic matter $=26.3 \mathrm{~g} \mathrm{dm}^{-3} ; \mathrm{pH}\left(\mathrm{H}_{2} \mathrm{O}\right)$ = 5.9; $\mathrm{P}($ Mehlich $)=6.9 \mathrm{mg} \mathrm{dm}^{-3} ; \mathrm{K}=$ $313 \mathrm{mg} \mathrm{dm}^{-3} ; \mathrm{Ca}=1.9 \mathrm{cmol} \mathrm{dm}^{-3} ; \mathrm{Mg}=$ $0.9 \mathrm{cmol}_{\mathrm{c}} \mathrm{dm}^{-3} ; \mathrm{H}+\mathrm{Al}=3.7 \mathrm{cmol}_{\mathrm{c}} \mathrm{dm}^{-3}$; $\mathrm{CTC}=7.3 \mathrm{cmol}_{\mathrm{c}} \mathrm{dm}^{-3}$ and $\mathrm{V}=49.3 \%$. For the conventional system: organic matter $=33.7 \mathrm{~g} \mathrm{dm}^{-3} ; \mathrm{pH}\left(\mathrm{H}_{2} \mathrm{O}\right)=5.2$; $\mathrm{P}($ Mehlich $)=1.0 \mathrm{mg} \mathrm{dm}^{-3} ; \mathrm{K}=462.0$ $\mathrm{mg} \mathrm{dm}{ }^{-3} ; \mathrm{Ca}=4.6 \mathrm{cmol}_{\mathrm{c}} \mathrm{dm}^{-3} ; \mathrm{Mg}=$ $0.7 \mathrm{cmol}_{\mathrm{c}} \mathrm{dm}^{-3} ; \mathrm{H}+\mathrm{Al}=6.2 \mathrm{cmol}_{\mathrm{c}} \mathrm{dm}^{-3}$; $\mathrm{CTC}=12.7 \mathrm{cmol}_{\mathrm{c}} \mathrm{dm}^{-3}$ and $\mathrm{V}=51.0 \%$.

The fertilizations in organic system were done in planting furrows containing $28,750 \mathrm{~kg} \mathrm{ha}^{-1}$ organic compost, according to the recommendation of Couto et al. (2008) and $1,250 \mathrm{~kg} \mathrm{ha}^{-1}$ of magnesian thermophosphate $(2.0 \%$ $\mathrm{N}, 10.0 \% \mathrm{P}_{2} \mathrm{O}_{5}, 7.0 \% \mathrm{~K}_{2} \mathrm{O}, 8.0 \% \mathrm{Ca}$ and $1.0 \% \mathrm{Mg}$ ). For the conventional system, fertilization was done using a mixture of urea, superphosphate and potassium chloride, at doses of $190 \mathrm{~kg}$ $\mathrm{ha}^{-1} \mathrm{~N}, 420 \mathrm{~kg} \mathrm{ha}^{-1} \mathrm{P}_{2} \mathrm{O}_{5}$ and $210 \mathrm{~kg} \mathrm{ha}^{-1}$ $\mathrm{K}_{2} \mathrm{O}$. Hilling up in both experiments was carried out about 40 days after planting. Weeds, pests and diseases control was performed through manual weeding for organic system and using metribuzin herbicide at a dose of $480 \mathrm{~g}$ of active ingredient/ha applied 6 days after planting in the conventional system.

The experiments were carried out in a randomized blocks experimental design, with three replicates. Useful area of the plot consisted of a row with 10 plants, spaced $0.80 \mathrm{~m}$ between lines and $0.35 \mathrm{~m}$ between plants.

After harvests, the following yield traits were evaluated: total tuber mass, in $\mathrm{kg}$ (TTM), marketable tuber mass, in $\mathrm{kg}$ 
(MTM) and number of marketable tubers (NMT), considering as marketable, the tubers showing a transverse diameter above $45 \mathrm{~mm}$.

Data were standardized to production per hectare based on plant population quantified 50 to 60 days after planting in plots individually. Individual and joint variance analyses were performed. Then, analyses of variance and ScottKnott average clustering $(\mathrm{p} \leq 0.05)$ using statistical software Genes (Cruz, 2013) were carried out.

\section{RESULTS AND DISCUSSION}

Significant difference among genotypes for all evaluated traits was observed. We also verified significant interaction between genotypes, years and production systems for all traits that measure marketable tuber productivity, i.e. marketable tuber mass (MTM) and number of marketable tubers (NMT) (data not shown). For total tuber mass (TTM), although a significant effect of the factor systems (data not shown) was observed, no significant change in the classification of genotypes in different years or systems was noticed (Table 1). Variation coefficients were low (between $13.74 \%$ for TTM and $18.17 \%$ for MTM), considering that yield traits are quantitative and, as a consequence, result in a greater environmental influence than the qualitative traits (Silva et al., 2016).

In relation to TTM, genotypes F158-08-01, F158-08-02, F183-08-01, F21-09-07, F97-07-03 and PCDSE090 were the most productive over the years and cultivation systems, outperforming even the controls (Table 1).

In relation to MTM, which is the most important trait, the average production in $2016\left(23.99 \mathrm{t} \mathrm{ha}^{-1}\right)$ was higher than in $2017\left(17.48 \mathrm{tha}^{-1}\right)$. This might have been explained by the time the seeds remained in a cold chamber in the second year, because the longer the seed tubers remain stored, the greater their sprouting, which results in plants with a greater number of stems, greater total number and smaller size of tubers in the subsequent harvest (Bisognin \& Streck, 2009). This was evident observing the cultivar Agata, which has fast sprouting and showed marketable tuber productivity about $50 \%$ lower in the second harvest.

In 2016 harvest, genotypes with higher MTM were F158-08-01, F15808-02 and F183-08-01. Also, genotypes F102-08-04, F18-09-03, F21-09-07, F63-10-07, F97-07-03, PCDINV10 and PCDSE090 showed to be superior to controls (Table 1).

In 2017 harvest, genotypes F15808-01 and F158-08-02 were the most productive. These two genotypes also maintained similar yield in both evaluated harvests and production systems. Genotypes F183-08-01, F3108-05, F63-10-07 and F97-07-03 also presented results superior to controls (Table 1).

Genotypes F158-08-01 and F15808-02 were superior to the others under organic system, considering marketable tuber mass. Genotypes F13-09-03, F-1809-03, F-183-08-01, F-21-09-07, F3108-05, F63-10-07 and F97-07-03 also outperformed the controls under this production system. For the conventional system, genotypes F158-08-01, F15808-02 and F183-08-01 were superior. Genotypes F18-09-03, F21-09-07, F63-10-07, F97-07-03, PCDINV10 and PCDSE090 showed performance similar to the most productive control (Asterix). Comparing organic and conventional systems, most genotypes showed better yields under conventional system, on average, about $75 \%$ more (Table 2); however, the most productive genotypes, F158-08-01 and F158-08-02, showed similar performance under the two systems (Table 1).

Considering the number of marketable tubers, most genotypes, especially the most productive ones, had fewer marketable-sized tubers in 2017, when seeds were kept for a longer time in a cold chamber. Genotypes F158-0802 and F21-09-07 produced a greater quantity of marketable tubers in 2016 , considering that genotype F158-08-02 also showed greater quantity in 2017 , not differing statistically from genotype

Table 1. Clustering of means of the evaluation of potato genotypes for total tuber mass (TTM) and marketable tuber mass (MTM), in Brasília-DF under organic and conventional systems, 2016 and 2017 harvests. Brasília, Embrapa, 2019.

\begin{tabular}{|c|c|c|c|c|c|}
\hline \multirow{3}{*}{ Genotypes } & \multirow{3}{*}{$\operatorname{TTM}\left(\mathrm{t} \mathrm{ha}^{-1}\right)$} & \multicolumn{4}{|c|}{$\operatorname{MTM}\left(\mathrm{t} \mathrm{ha}^{-1}\right)$} \\
\hline & & \multicolumn{2}{|c|}{ Year } & \multicolumn{2}{|c|}{ System } \\
\hline & & 2016 & 2017 & Organic & Conventional \\
\hline F-102-08-04 & $26.16 \mathrm{~B}$ & $20.53 \mathrm{Ba}$ & $13.00 \mathrm{Cb}$ & $7.66 \mathrm{Cb}$ & $28.71 \mathrm{Ba}$ \\
\hline F-117-08-06 & $22.12 \mathrm{~B}$ & $15.32 \mathrm{Ca}$ & $8.11 \mathrm{Db}$ & $6.65 \mathrm{Cb}$ & $17.45 \mathrm{Ca}$ \\
\hline F-13-09-03 & $32.14 \mathrm{~B}$ & $19.88 \mathrm{Ca}$ & $16.63 \mathrm{Ca}$ & $15.23 \mathrm{Bb}$ & $21.46 \mathrm{Ca}$ \\
\hline F-158-08-01 & $48.77 \mathrm{~A}$ & $39.88 \mathrm{Aa}$ & $37.37 \mathrm{Aa}$ & $37.55 \mathrm{Aa}$ & $39.69 \mathrm{Aa}$ \\
\hline F-158-08-02 & $52.93 \mathrm{~A}$ & $44.79 \mathrm{Aa}$ & $32.68 \mathrm{Aa}$ & $37.97 \mathrm{Aa}$ & $39.04 \mathrm{Aa}$ \\
\hline F-18-09-03 & $30.78 \mathrm{~B}$ & $27.83 \mathrm{Ba}$ & $15.60 \mathrm{Cb}$ & $13.45 \mathrm{Bb}$ & $30.86 \mathrm{Ba}$ \\
\hline F-183-08-01 & $45.31 \mathrm{~A}$ & $35.40 \mathrm{Aa}$ & $24.28 \mathrm{Bb}$ & $19.34 \mathrm{Bb}$ & $41.94 \mathrm{Aa}$ \\
\hline F-21-09-07 & $36.17 \mathrm{~A}$ & $27.78 \mathrm{Ba}$ & $16.69 \mathrm{Cb}$ & $14.44 \mathrm{Bb}$ & $30.84 \mathrm{Ba}$ \\
\hline F-22-08-01 & 17.26 B & $11.29 \mathrm{Da}$ & $9.55 \mathrm{Da}$ & $10.48 \mathrm{Ca}$ & $10.32 \mathrm{Da}$ \\
\hline F-31-08-05 & $27.82 \mathrm{~B}$ & $14.31 \mathrm{Cb}$ & $21.94 \mathrm{Ba}$ & $16.54 \mathrm{Ba}$ & $19.37 \mathrm{Ca}$ \\
\hline F-37-08-01 & $16.46 \mathrm{~B}$ & $8.75 \mathrm{Da}$ & $10.59 \mathrm{Da}$ & $5.59 \mathrm{Cb}$ & $14.74 \mathrm{Ca}$ \\
\hline F-63-10-07 & $31.14 \mathrm{~B}$ & $22.39 \mathrm{Ba}$ & $23.81 \mathrm{Ba}$ & $16.84 \mathrm{Bb}$ & $30.31 \mathrm{Ba}$ \\
\hline F-97-07-03 & $37.33 \mathrm{~A}$ & $27.55 \mathrm{Ba}$ & $22.68 \mathrm{Ba}$ & $18.48 \mathrm{Bb}$ & $32.61 \mathrm{Ba}$ \\
\hline Agata & $20.08 \mathrm{~B}$ & $16.21 \mathrm{Ca}$ & $8.97 \mathrm{Db}$ & $6.93 \mathrm{Cb}$ & $19.22 \mathrm{Ca}$ \\
\hline Asterix & $27.91 \mathrm{~B}$ & $17.49 \mathrm{Ca}$ & $13.79 \mathrm{Ca}$ & $9.63 \mathrm{Cb}$ & $22.91 \mathrm{Ba}$ \\
\hline PCDINV10 & $29.05 \mathrm{~B}$ & $29.42 \mathrm{Ba}$ & $8.16 \mathrm{Db}$ & $11.50 \mathrm{Cb}$ & $23.98 \mathrm{Ba}$ \\
\hline PCDSE090 & $36.76 \mathrm{~A}$ & $29.01 \mathrm{Ba}$ & $13.39 \mathrm{Cb}$ & $11.81 \mathrm{Cb}$ & $31.43 \mathrm{Ba}$ \\
\hline
\end{tabular}

Averages followed by same lowercase letters in line or same uppercase letters in column belong to the same group based on Scott-Knott clustering test, $5 \%$ probability. 
F63-10-07. Genotypes F158-08-01 and F158-08-02 presented the highest number of marketable tubers under organic system. Genotypes F158-08-02, F21-09-07 and PCDSE090 showed the greatest number of marketable tubers under conventional system (Table 3 ).

According to Nazareno (2009), the organic cultivation differs from the conventional in several aspects. In organic system, low solubility fertilizer sources are used, such as organic composts or rocks (whereas in conventional cultivation, high doses of soluble fertilizers are applied to the planting lines), and insecticides and fungicides commonly used in conventional system are not allowed for use in the organic system. For pest and disease control, only natural chemical and biological substances, extracts and organisms are allowed. Since fewer products to control pests and diseases are allowed in organic cultivation, the use of tolerant or resistant cultivars is even more important. Thus, genotypes that are more resistant to diseases such as late blight (Phytophthora infestans) and early blight (Alternaria solani), tend to show a better performance under the organic system. In this study, these diseases were not observed, even under organic cultivation, which is a consequence of the adoption of preventive measures, in particular, the cultivation in a less disease-prone season. Then, we observed that the disease tolerance factor did not represent a competitive advantage among the studied genotypes.

The average yield of marketable tubers considering the two years was $15.30 \mathrm{t} \mathrm{ha}^{-1}$ and $26.75 \mathrm{t} \mathrm{ha}^{-1}$ under organic and conventional system, respectively (Table 2). However, yields close to $40 \mathrm{t} \mathrm{ha}^{-1}$ were obtained for the most productive genotypes in both systems (Table 1). Rossi et al. (2011) evaluated 18 potato genotypes in organic system in São Paulo State, considering as marketable those tubers with transversal diameter above 40 $\mathrm{mm}$, and they verified productivity of marketable tubers ranging from 3.78 to $18.07 \mathrm{t} \mathrm{ha}^{-1}$. Those authors also verified that tolerance to early blight was important, due to the occurrence of this disease, considering that cultivar Agata and, mainly, Asterix, were the

Table 2. Clustering of means of the evaluation of potato genotypes for marketable tuber mass (MTM) and number of marketable tubers (NMT), evaluated in Brasília-DF under organic and conventional systems, 2016 and 2017 harvests. Brasília, Embrapa, 2019.

\begin{tabular}{|c|c|c|c|}
\hline \multirow[b]{2}{*}{ System } & \multirow{2}{*}{$\operatorname{MTM}\left(\mathbf{t ~ h a}^{-1}\right)$} & \multicolumn{2}{|c|}{ NMT ha-1/1000 } \\
\hline & & 2016 & 2017 \\
\hline Organic & $15.30 \mathrm{~B}$ & $83.95 \mathrm{Ba}$ & $52.72 \mathrm{Bb}$ \\
\hline Conventional & $26.75 \mathrm{~A}$ & $206.55 \mathrm{Aa}$ & $119.21 \mathrm{Ab}$ \\
\hline
\end{tabular}

Averages followed by same lowercase letters in line or same uppercase letters in column belong to the same group based on Scott-Knott clustering test, 5\% probability.

Table 3. Clustering of means of the evaluation of potato genotypes for number of marketable tubers (NMT) per hectare/1000, evaluated in Brasília-DF under organic and conventional systems, 2016 and 2017 harvests. Brasília, Embrapa, 2019.

\begin{tabular}{lccccc}
\hline \multirow{2}{*}{ Genotypes } & \multicolumn{2}{c}{ Year } & & \multicolumn{2}{c}{ System } \\
\cline { 2 - 3 } \cline { 6 - 7 } & $\mathbf{2 0 1 6}$ & $\mathbf{2 0 1 7}$ & & Organic & Conventional \\
\hline F-102-08-04 & $155.92 \mathrm{Ba}$ & $75.65 \mathrm{Bb}$ & & $49.98 \mathrm{Cb}$ & $199.11 \mathrm{Ba}$ \\
F-117-08-06 & $103.54 \mathrm{Ca}$ & $48.58 \mathrm{Cb}$ & & $37.95 \mathrm{Cb}$ & $120.61 \mathrm{Ca}$ \\
F-13-09-03 & $144.14 \mathrm{Ba}$ & $88.21 \mathrm{Bb}$ & & $88.04 \mathrm{Bb}$ & $144.35 \mathrm{Ca}$ \\
F-158-08-01 & $145.43 \mathrm{Ba}$ & $103.41 \mathrm{Bb}$ & & $117.15 \mathrm{Aa}$ & $130.08 \mathrm{Ca}$ \\
F-158-08-02 & $222.60 \mathrm{Aa}$ & $169.28 \mathrm{Ab}$ & & $141.23 \mathrm{Ab}$ & $257.46 \mathrm{Aa}$ \\
F-18-09-03 & $171.10 \mathrm{Ba}$ & $78.07 \mathrm{Bb}$ & & $72.10 \mathrm{Bb}$ & $180.21 \mathrm{Ba}$ \\
F-183-08-01 & $141.86 \mathrm{Ba}$ & $84.31 \mathrm{Bb}$ & & $55.61 \mathrm{Cb}$ & $185.82 \mathrm{Ba}$ \\
F-21-09-07 & $208.00 \mathrm{Aa}$ & $97.91 \mathrm{Bb}$ & & $85.68 \mathrm{Bb}$ & $226.79 \mathrm{Aa}$ \\
F-22-08-01 & $64.37 \mathrm{Da}$ & $56.78 \mathrm{Ca}$ & & $58.13 \mathrm{Ca}$ & $62.96 \mathrm{Ea}$ \\
F-31-08-05 & $78.96 \mathrm{Ca}$ & $102.24 \mathrm{Ba}$ & & $76.87 \mathrm{Ba}$ & $104.64 \mathrm{Da}$ \\
F-37-08-01 & $60.01 \mathrm{Da}$ & $69.05 \mathrm{Ca}$ & & $42.82 \mathrm{Cb}$ & $90.44 \mathrm{Da}$ \\
F-63-10-07 & $138.24 \mathrm{Ba}$ & $122.02 \mathrm{Aa}$ & & $87.32 \mathrm{Cb}$ & $181.10 \mathrm{Ba}$ \\
F-97-07-03 & $147.28 \mathrm{Ba}$ & $111.24 \mathrm{Bb}$ & & $80.79 \mathrm{Cb}$ & $187.49 \mathrm{Ba}$ \\
Agata & $116.66 \mathrm{Ca}$ & $54.02 \mathrm{Cb}$ & & $42.04 \mathrm{Cb}$ & $136.04 \mathrm{Ca}$ \\
Asterix & $111.63 \mathrm{Ca}$ & $79.95 \mathrm{Ba}$ & & $49.98 \mathrm{Cb}$ & $154.60 \mathrm{Ca}$ \\
PCDINV10 & $196.73 \mathrm{Aa}$ & $63.84 \mathrm{Cb}$ & & $67.39 \mathrm{Bb}$ & $190.65 \mathrm{Ba}$ \\
PCDSE090 & $226.32 \mathrm{Aa}$ & $42.85 \mathrm{Cb}$ & & $36.37 \mathrm{Cb}$ & $242.01 \mathrm{Aa}$ \\
\hline
\end{tabular}

Averages followed by same lowercase letters in line or same uppercase letters in column belong to the same group based on Scott-Knott clustering test, $5 \%$ probability. most affected ones. Passos et al. (2017) evaluated 8 potato cultivars under organic system in three experiments in the Southern Brazil and verified, in average of the experiments, marketable yield from 12 to $22.70 \mathrm{t} \mathrm{ha}^{-1}$.

Silva et al. (2017) evaluated 13 advanced potato clones, and also the cultivars Agata and Asterix, in organic and conventional production systems in 2016 in Brasília-DF, some of the clones being the same evaluated herein. The authors observed a great range in marketable yields of different genotypes in the organic system, from 3.50 to 38.75 $\mathrm{t} \mathrm{ha}^{-1}$, with an average value of $13.50 \mathrm{t}$ $\mathrm{ha}^{-1}$; whereas in an area nearby, under a conventional system, the average yield of marketable tubers was quite superior $\left(21.66 \mathrm{t} \mathrm{ha}^{-1}\right)$. In the Silva et al. (2017) study, clones F158-08-01 and F15808-02 showed good performance and they were superior to the other clones in both production systems, considering that the clone F183-08-01 also grouped among the most productive ones in the conventional system. In relation to the lower yield obtained in organic systems, 
according to Nazareno (2009), it is compensated by the higher prices paid by the consumers of organic products.

Silva et al. (2018b) evaluated a group of nine advanced potato clones, in Canoinhas-SC and Pelotas-RS (Southern Brazil) and Brasília-DF (Brazilian Center-West) in a conventional cultivation system, the same results of this study for clones F21-09-07 and F183-08-01 being verified. The authors verified that clone F21-09-07 was superior to the others in relation to productivity and frying quality, the clone F183-08-01 being one of the most productive in Brasília-DF, though. In relation to marketable tuber mass in Brasília-DF, clones F21-09-07 and F183-08-01 produced $28.59 \mathrm{t} \mathrm{ha}^{-1}$ and $41.07 \mathrm{t} \mathrm{ha}^{-1}$, respectively, quite similar to the present study (30.84 and $41.94 \mathrm{t}$ ha $^{-1}$, respectively, under conventional production system).

Despite the lower average yield of tubers in organic system, it was possible to select genotypes with high productive potential in this system, mainly F15808-01 and F158-08-02, with high yield of marketable tubers, the values in organic cultivation being almost equivalent to the conventional system. Genotypes F102-08-04, F13-09-07, F-18-09-03, F-183-08-01, F-21-09-07, F31-08-05, F63-10-07 and F97-07-03 also outperformed controls in organic system. For conventional system, genotypes F158-08-01, F158-08-02 and F183-08-01 were superior, genotypes F18-09-03, F21-09-07, F63-10-07, F97-07-03, PCDINV10 and PCDSE090 showed similar or superior performance comparing with the most productive control (Asterix). Genotypes F158-0801 and F158-08-02 were superior in both systems and show potential to become new recommended cultivars for both production systems.

\section{REFERENCES}

BISOGNIN, DA; STRECK, NA. 2009. Desenvolvimento e manejo das plantas para alta produtividade e qualidade da batata. Itapetininga: ABBA. 27p.

COUTO, JR; RESENDE, FV; SOUZA, RB; SAMINEZ, TCO. 2008. Instruções práticas para produção de composto orgânico em pequenas propriedades. Brasília: Embrapa Hortaliças, 8p. (Comunicado Técnico 53).

CRUZ, CD. 2013. Genes; a software package for analysis in experimental statistics and quantitative genetics. Acta Scientiarum Agronomy 35: 271-276.

IBGE - Instituto Brasileiro de Geografia e Estatística. 2019. Available at Levantamento Sistemático da Produção Agrícola. Rio de Janeiro: IBGE. <https://sidra.ibge.gov.br/ home/lspa $>$. Accessed January 20, 2019.

FAOSTAT. 2015. Production quantities by country average 1993 - 2013. Available at $<\mathrm{http} / / /$ faostat3.fao.org/browse/Q/QC/E $>$. Accessed
January 30, 2019.

NAZARENO, NRX. 2009. Produção orgânica de batata - potencialidades e desafios. Londrina: IAPAR. 249p.

PASSOS, S; KAWAKAMI, J; NAZARENO, NRX; SANTOS, KC; TAMANINI JUNIOR, C. 2017. Produtividade de cultivares de batata orgânica em região subtropical do Brasil. Horticultura Brasileira 35: 628-633.

ROSSI, F; MELO, PCT; AZEVEDO FILHO, JA; AMBROSANO, EJ; GUIRADO, N; SCHAMMASS, EA; CAMARGO, LF. 2011. Cultivares de batata para sistemas orgânicos de produção. Horticultura Brasileira 29: 372-376.

SILVA, GO; BORTOLETTO, AC; CARVALHO, AD; PEREIRA, AS. 2018a. Effect of potassium sources on potato tuber yield and chip quality. Horticultura Brasileira 36: 395-398.

SILVA, GO; BORTOLETTO, AC; PONIJALEKI, R; MOGOR, AF; PEREIRA, AS. 2014. Desempenho de cultivares nacionais de batata para produtividade de tubérculos. Revista Ceres 61: 752-756.

SILVA, GO; CARVALHO ADF; PEREIRA AS; RAGASSI, CF; AZEVEDO FQ. 2017. Desempenho de clones avançados de batata para rendimento de tubérculos em quatro ambientes.Agro@mbiente 11: 323-330.

SILVA, GO; PEREIRA AS; AZEVEDO FQ; CARVALHO ADF. 2016. Avaliação de clones de batata para caracteres de rendimento e qualidade de fritura. Revista Latinoamericana de la Papa 20: 37-44.

SILVA, GO; PEREIRA, AS; CARVALHO, ADF; AZEVEDO, FQ. 2018b. Seleção genotípica de clones de batata para rendimento de tubérculos, aspecto vegetativo e qualidade de fritura. Revista Brasileira de Ciências Agrárias 13: e5534. 